\title{
PCR for the Detection of Extended Spectrum $\beta$-Lactamases Genes of Pseudomonas aeruginosa
}

\author{
Farqad A. Aljanabi, Haider A. Alnaji, Alkarar K. Duaibel*
}

Department of Clinical Laboratory Investigations Techniques, Islamic University, Najaf, Iraq

*Corresponding author

\section{A B S T R A C T}

\begin{tabular}{|c|}
\hline Keywords \\
\hline $\begin{array}{l}\text { ESBLs, } \text { Pseudomonas } \\
\text { aeruginosa, } \text { bla }_{\text {-TEM }}, \text { bla } \\
\text { sHv, } \text { bla-CTX-M, } \text { bla }_{\text {-AmpC }} \text {, } \\
\text { genes, PCR, MDRPA, } \\
\text { Nosocomial infections }\end{array}$ \\
\hline Article Info \\
\hline $\begin{array}{l}\text { Accepted: } \\
04 \text { October } 2018 \\
\text { Available Online: } \\
10 \text { November } 2018\end{array}$ \\
\hline
\end{tabular}

\section{Keywords}

Extended spectrum $\beta$-lactamases are often plasmid mediated and derived from mutations in $b l a_{\text {-TEM }}, b l a_{\text {-SHV }}, b l a_{\text {-CTX-M }}$, and $b l a_{\text {-AmpC }}$ genes by one or more amino acid substitution around the active site. These genes are responsible for resistance to beta lactams in Pseudomonas aeruginosa. In this study, Pseudomonas aeruginosa were isolated from wound and burn infection patients admitted to Diwanyia Teaching Hospital. Routine microbiological methods were used then PCR technique for the detection of four extended spectrum $\beta$-lactamases genes ( bla $_{\text {-TEM }}, b l a_{\text {-SHV }}, b l a_{\text {-CTX-M }}$, and $\left.b l a_{\text {-AmpC }}\right)$. The PCR results indicated high prevalence of Extended-spectrum $\beta$-lactamases in burn infections ( $b l a_{\text {-TEM }}$ (66.7\%), bla $a_{\text {-SHV }}(86.7 \%)$, bla $_{\text {-СTX-M }}(93.3 \%)$, and bla $_{\text {-AmpC }} \mathrm{C}(53.3 \%)$ and less prevalent in wound infections infected with Pseudomonas aeruginosa $\left(\right.$ bla $_{\text {-TEM }}(59.1 \%)$, bla -SHV $_{\text {S }}$ (68.2\%), bla -СтХ-м $(81.8 \%)$, and bla $a_{\text {-AmpC }}(50 \%)$. In conclusion, Pseudomonas aeruginosa isolates of wound and burn infection patients are highly associated with emergence of extended spectrum $\beta$-lactamases genes that provide antibacterial resistance to almost broad spectrum antibiotics.

\section{Introduction}

Pseudomonas aeruginosa is one of the widely occurred as an opportunistic pathogen, causing outbreaks of nosocomial infections including pneumonia, urinary tract infections, and bacteremia (Bahmani and Ramazanzadeh, 2013; Wirth et al., 2009). Nosocomial infections caused by $P$. aeruginosa are frequently life threatening and often difficult to treat; due to its capacity to develop resistance to multiple classes of antimicrobials through both intrinsic mechanisms and acquisition of transferable resistance determinants (e.g., genes encoding $\beta$ - lactamases) (Umadevi et al., 2011; Tian et al., 2011). Eventually leading to the emergence of multidrug-resistant $P$. aeruginosa (MDRPA) strain (Peymani et al., 2017). P. aeruginosa (MDRPA) is involved in the production of various classes of extended spectrum $\beta$ lactamases (ESBLs) (Bokaeian et al., 2015).

Extended-spectrum $\beta$-lactamases (ESBLs) are enzymes that hydrolyze penicillin, monobactam aztreonam (ATM)) and extended-spectrum cephalosporins (cefotaxime (CTX), ceftazidime (CAZ) and ceftriaxone) (Jiang et al., 2006). The clavulanic acid is $\beta$-lactamase inhibitor 
capable of inhibit ESBLs (Rafiee et al., 2014). The extended-spectrum $\beta$-lactamases are plasmid-encoded enzymes and the major genetic groups of ESBLs are TEM, SHV, and CTX-M that mediate resistance to wide range of antibiotics' generation (Peymani et al., 2017). On the other hand, $P$. aeruginosa produce chromosomal AmpC-lactamase, which mediate high-level penicillin and cephalosporin resistance (Tian et al., 2011).

Unfortunately, the emergence of extendedspectrum $\quad \beta$-lactamases (ESBLs) $P$. aeruginosa, among hospitalized patients in burn units is life-threating because the burn patient's infection is one of the most complicated issue since these strains are multidrug-resistant and challenging to treat (Radan et al., 2016). So it is obvious that using PCR in the detection of TEM, SHV, CTX and AmpC genes in ESBL-producing bacteria and their pattern of antimicrobial resistance is quite important; For the establishment of the appropriate antimicrobial therapy and for assessment and control of the spread of drug resistant $P$. aeruginosa (Bokaeian et al., 2015; Polotto et al., 2012).

\section{Materials and Methods}

\section{Sample collection}

50swab samples were collected from wound and burn, infection from patients of Diwanyiaprovince/Iraq. The samples were placed in sterile transport media then transferred to the Microbiology Laboratory / College of Veterinary Medicine and store in a refrigerator until microbiological processing.

\section{Bacterial isolation}

Pseudomonas aeruginosa was isolated from wound and burn samples by inoculation on Brain Heart Infusion Broth medium at $37^{\circ} \mathrm{C}$ overnight for primary enrichment culture and then the bacterial growth were inoculated on chrome agar at $37^{\circ} \mathrm{C}$ overnight for selective isolation of pure culture of Pseudomonas aeruginosa isolates.

\section{Bacterial genomic DNA extraction}

Bacterial genomic DNA was extracted from P.aeruginosa isolates using (Presto ${ }^{\mathrm{TM}}$ Mini gDNA Bacteria Kit. Geneaid. USA). One ml of overnight bacterial growth on BHI broth was placed in $1.5 \mathrm{ml}$ microcentrifuge tubes and centrifuged at $10000 \mathrm{rpm}$ for 1 minute. The supernatant was discarded and the bacterial cells pellets were used in genomic DNA extraction and the extraction was made according to the manufactural instructions. The extracted gDNA was checked by "Nano drop" spectrophotometer, then storedat-20Cin refrigerator until PCR assay.

\section{Polymerase chain reaction (PCR)}

PCR was performed for the detection of Extended-spectrum $\beta$-lactamases (ESBLs) (bla $a_{\mathrm{TEM}}, b l a_{-\mathrm{SHV}}, b l a_{-\mathrm{CTX}-\mathrm{M}}$, and $b l a_{\mathrm{AmpC}}$ genes) by using specific ESBLs primers designed by using NCBI-GenBank and primer3 plus design online. As shown in table 1.

These primers were provided by (Bioneer Company. Korea). Then PCR master mix was prepared using (AccuPower ${ }^{\circledR}$ PCR PreMix kit. Bioneer. Korea). The PCR premix tube contains freeze-dried pellet of (Taq DNA polymerase $1 \mathrm{U}$, dNTPs $250 \mu \mathrm{M}$, Tris- $\mathrm{HCl}(\mathrm{pH}$ 9.0) $10 \mathrm{mM}, \mathrm{KCl} 30 \mathrm{mM}, \mathrm{MgCl} 21.5 \mathrm{mM}$, stabilizer, and tracking dye) and the PCR master mix reaction was prepared according to kit instructions in $20 \mu 1$ total volume by added $5 \mu l$ of purified genomic DNA and $1.5 \mu 1$ of 10 pmole of forward primer and $1.5 \mu 1$ of 10pmole of reverse primer, then completing the PCR premix tube by deionizer PCR water into $20 \mu \mathrm{l}$ and briefly mixed by Exispin vortex centrifuge (Bioneer. Korea). The reaction was 
performed in a thermocycler (Mygene Bioneer. Korea) by seting up the following thermocycler conditions; initial denaturation temperature of $95{ }^{\circ} \mathrm{C}$ for $5 \mathrm{~min}$; followed by 30 cycles at denaturation $95{ }^{\circ} \mathrm{C}$ for $30 \mathrm{~s}$, annealing $60{ }^{\circ} \mathrm{C}$ for $30 \mathrm{~s}$, and extension $72{ }^{\circ} \mathrm{C}$ for $1 \mathrm{~min}$ and then final extension at $72{ }^{\circ} \mathrm{C}$ for $10 \mathrm{~min}$. The PCR products were examined by electrophoresis in a $1 \%$ agarose gel, stained with ethidium bromide, and visualized under UV transilluminator.

\section{Results and Discussion}

A total of 50 swab samples were collected from wound and burn infections; where wound infections were 32 and 18 were burn infections. Pseudomonas aeruginosa isolated from $22(68.7 \%)$ of wound infections samples, while in burn infections Pseudomonas aeruginosa isolated from $15(83.3 \%)$ of samples, the results are shown in the table 2 (Fig. 1-4).

\section{Molecular detection of ESBLs gens}

PCR appear to be specific for the detection of Extended-spectrum $\beta$-lactamases (ESBLs) (bla $a_{\mathrm{TEM}}, b a_{-\mathrm{SHV}}, b l a_{-\mathrm{CTX}-\mathrm{M}}$, and $b l a_{\mathrm{AmpC}}$ genes) producing Pseudomonas aeruginosa. The PCR results are shown in the table 3. The results of bla-TEM genotyping revealed that Thirteen $(59.1 \%)$ out of 22 isolates and 10 $(66.7 \%)$ out of 15 isolates were harboring blaTEM in wound and burn infections, respectively. The $b l a_{\text {-SHV }}$ gene was found in 15 $(68.2 \%)$ and $13(86.7 \%)$ in wound and burn infections, respectively.

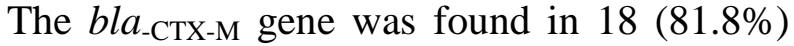
out of 22 isolates of $P$. aeruginosa in wound, while $14(93.3 \%)$ out of 15 isolates in burn infections, finally the results of $b l a_{\mathrm{AmpC}}$ genotyping revealed that $11(50 \%)$ out of 22 isolates and $8(53.3 \%)$ out of 15 isolates out of 15 isolates were harboring $b l a_{\mathrm{AmpC}}$ in wound and burn infections, respectively.
Hospitalized patients burn show increasingly emerging strains of ESBL-producing $P$. aeruginosa, especially; burn patients with prolonged intensive care (Uemura et al., 2010). In this study, the frequency of the ESBL genes including plasmid-encoded (bla-

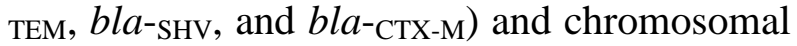
bla-AmpC among P.aeruginosa burn and wound isolates were studied. bla- ${ }_{\text {СтХ-м }}$ is the most dominant gene in both burn and wound isolates making $93.3 \%$ and $81.8 \%$ respectively.

This is in agreement with the results of Celenza who reported a high prevalence of bla-СтХ-м genes (Celenza et al., 2006).blaСтХ-м product, the plasmid-mediated cefotaximases, most of CTX-Ms unveil influential resistance for cefotaxime and ceftriaxone but not ceftazidime (Zhao and $\mathrm{Hu}$, 2013).

However, the frequency of the bla $a_{\text {-СтХ-м }}$ group of ESBL in thisstudy is higher as compared with other studies; in a study from Iran bla. CTX-M gene was detected only in one isolate (Shacheraghi et al., 2010). Another study reported a high prevalence of CTX-M genes in Enterobacteriaceae instead of Pseudomonas, as many genetic elements, lead to transfer of bla-СтХ-м genes from the chromosomes to plasmids (Zhao and $\mathrm{Hu}, 2013$ ). As well as the presence of bla-CTX-M gene in Pseudomonas aeruginosa is more likely result of horizontal transmission from Enterobacteriaceae (Polotto et al., 2012). This may interpret presence the variations within different geographical areas.

TEM, SHV and CTX genotypes are predominant within members of the family Enterobacteriaceae in different Asian countries. The presence these genes in $P$. aeruginosa were described recently (Chen et al., 2015). The present results indicate that $86.7 \%$ of isolates that possess $b l a_{\mathrm{SHV}}$ were isolated from burns whereas $68.2 \%$ of the isolates were from wounds. 
Table.1 The name, sequence and products size of primers

\begin{tabular}{|c|c|c|c|}
\hline Primer & \multicolumn{2}{|r|}{ Sequence } & Size of PCR product \\
\hline \multirow[t]{2}{*}{ bla } & $\mathbf{F}$ & AGC GAT AAC GTG GCG ATG AA & \multirow[t]{2}{*}{ 247bp } \\
\hline & $\mathbf{R}$ & TCA TCC ATG TCA CCA GCT GC & \\
\hline \multirow[t]{2}{*}{$b l a a_{\text {SHV }}$} & $\mathbf{F}$ & CCG CCA TTA CCA TGA GCG AT & \multirow[t]{2}{*}{ 410bp } \\
\hline & $\mathbf{R}$ & AAT CAC CAC AAT GCG CTC TG & \\
\hline \multirow[t]{2}{*}{ bla-TEM } & $\mathbf{F}$ & GGT GCA CGA GTG GGT TAC AT & \multirow[t]{2}{*}{ 531bp } \\
\hline & $\mathbf{R}$ & TGC AAC TTT ATC CGC CTC CA & \\
\hline \multirow[t]{2}{*}{ bla-AmpC } & $\mathbf{F}$ & AAA CGA CGC TCT GCA CCT TA & \multirow[t]{2}{*}{ 670bp } \\
\hline & $\mathbf{R}$ & TGT ACT GCC TTA CCT TCG CG & \\
\hline
\end{tabular}

Table.2 Isolation frequency

\begin{tabular}{|c|c|c|c|}
\hline Sample type & Total samples & Positive isolate & Percent \\
\hline Wound & 32 & 22 & $68.7 \%$ \\
\hline Burn & 18 & 15 & $83.3 \%$ \\
\hline
\end{tabular}

Table.3 Percent of genes presence among isolates

\begin{tabular}{|c|c|c|}
\hline Virulence gene & \multicolumn{2}{|c|}{ Clinical isolates } \\
\hline & Wound (22) & Burn (15) \\
\hline bla-TEM & $13 / 22(59.1 \%)$ & $10 / 15(66.7 \%)$ \\
\hline bla-SHV & $15 / 22(68.2 \%)$ & $13 / 15(86.7 \%)$ \\
\hline bla-CTX-M & $18 / 22(81.8 \%)$ & $14 / 15(93.3 \%)$ \\
\hline bla-AmpC & $11 / 22(50.0 \%)$ & $8 / 15(53.3 \%)$ \\
\hline
\end{tabular}

Fig.1 Agarose gel electrophoresis of PCR products of bla-СтХ-м gene (247bp). 1.5\% agarose gel at 7 volts/cm for 1 hour. Lane 1, 2, 4, 5, 7, 8: positive for bla-СтХ-м gene, lane 3, 7 were negative,

M: 100-bp DNA marker

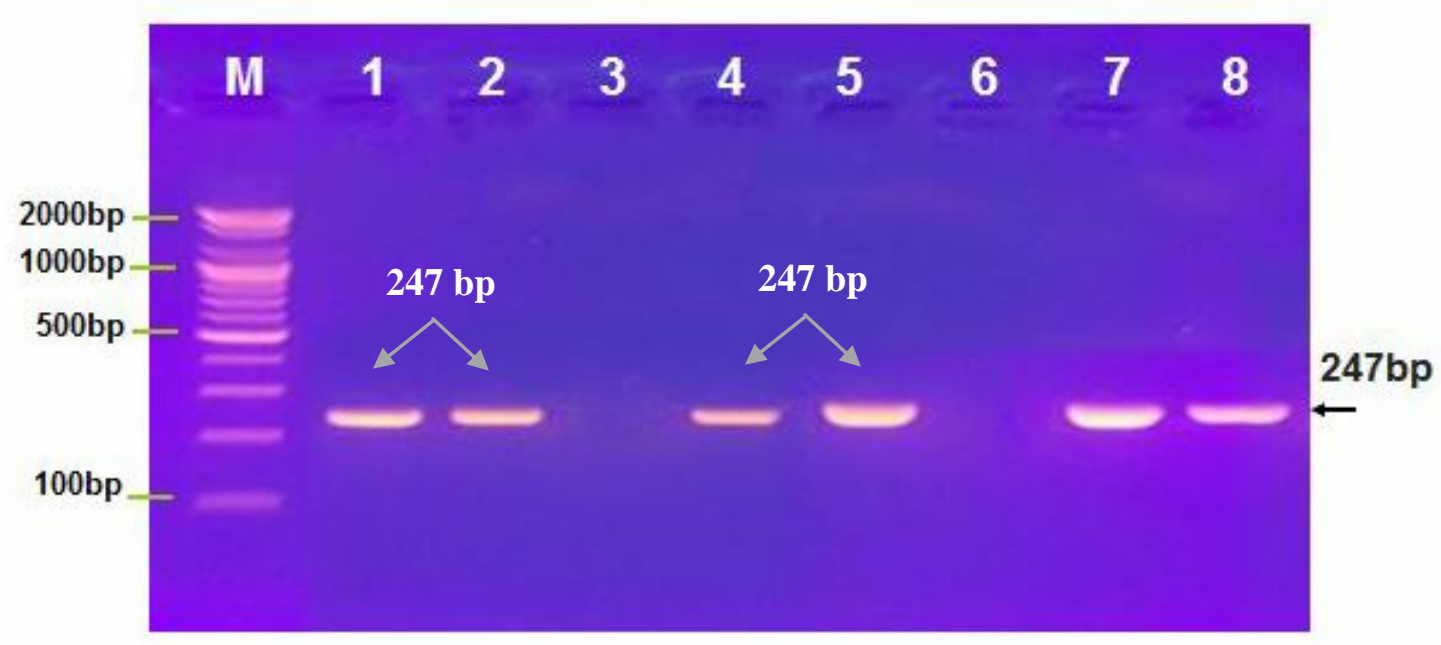


Fig.2 Agarose gel electrophoresis of PCR products of bla-TEM gene (531bp). $1.5 \%$ agarose gel at 7 volts/cm for 1 hour. Lane 1, 3, 5, 6, 7, 9, 10: positive for bla-TEM gene, lane 2, 4, 8 were negative, M: 100-bp DNA marker

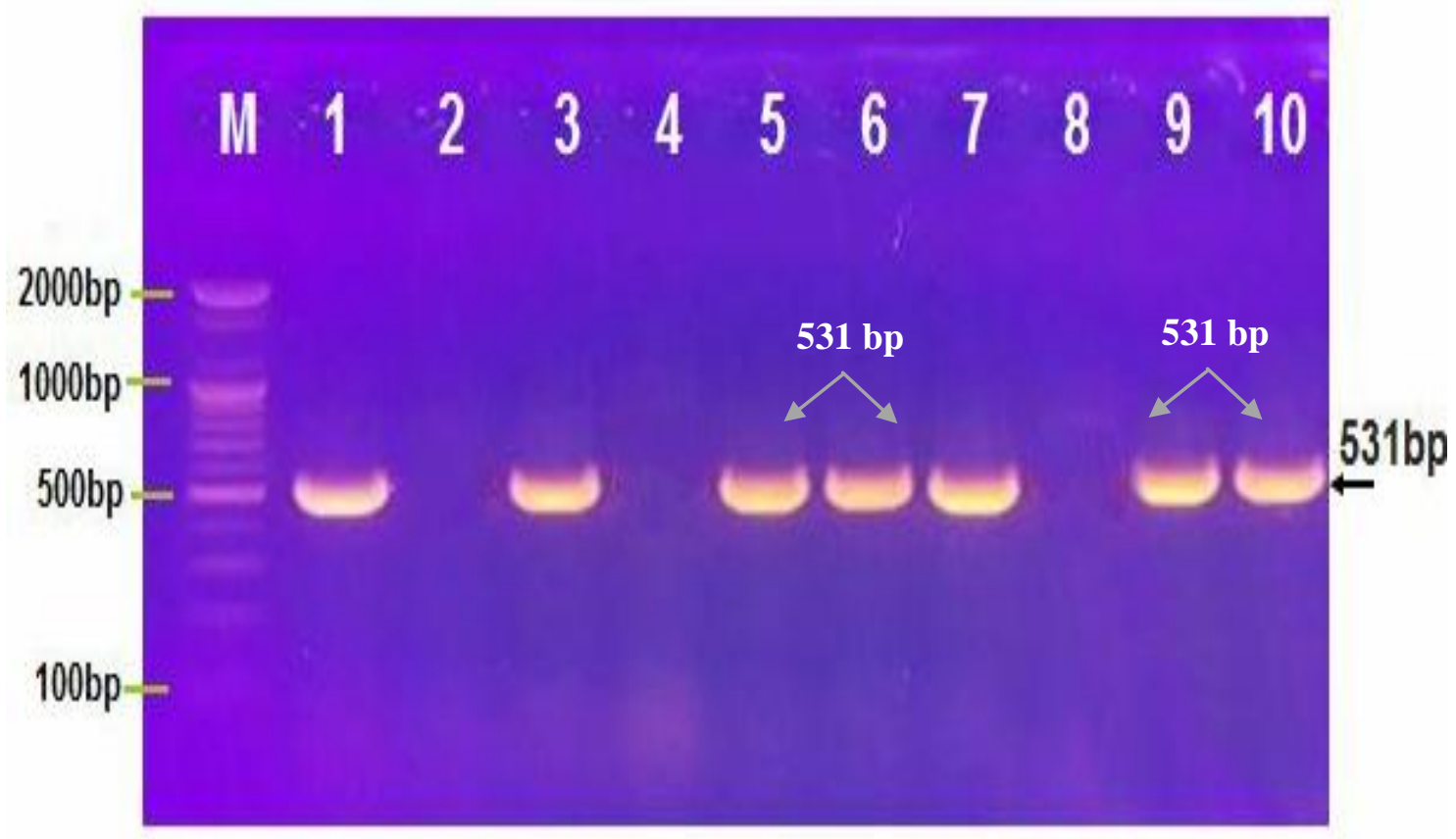

Fig.3 Agarose gel electrophoresis of PCR products of bla -SHV $_{\text {gene }}(410 \mathrm{bp}) .1 .5 \%$ agarose gel at 7 volts/cm for 1 hour. Lane 1, 3, 4, 5, 6, 7, 9, 10: positive for bla-sHv gene, lane 2, 8 were negative, M: 100-bp DNA marker

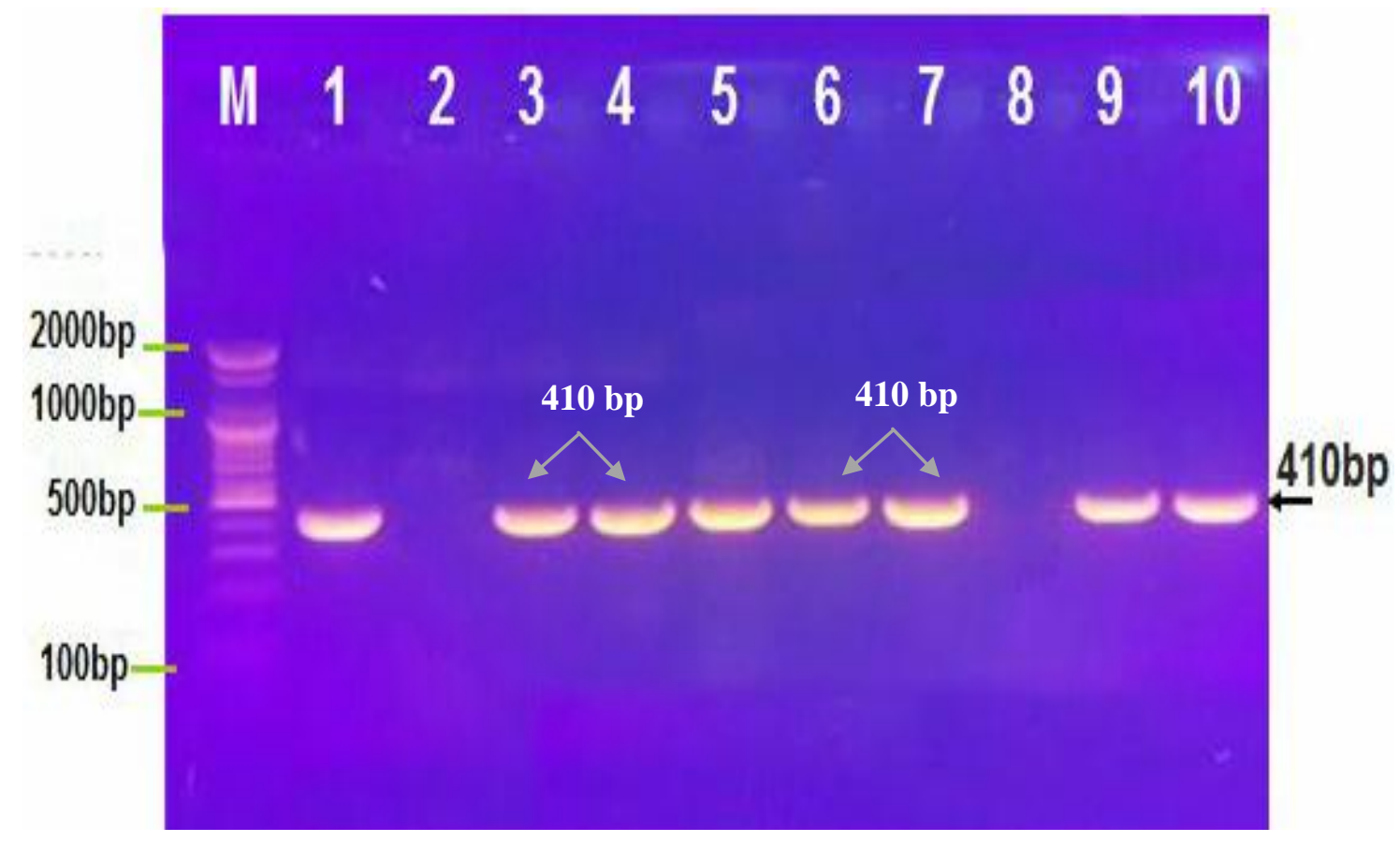


Fig.4 Agarose gel electrophoresis of PCR products of bla-AmpC gene (670bp). 1.5\% agarose gel at 7 volts/cm for 1 hour. Lane 1, 3, 4, 7, 8, 9, 10: positive for bla-AmpC gene, lane 2, 8 were negative, M: 100-bp DNA marker

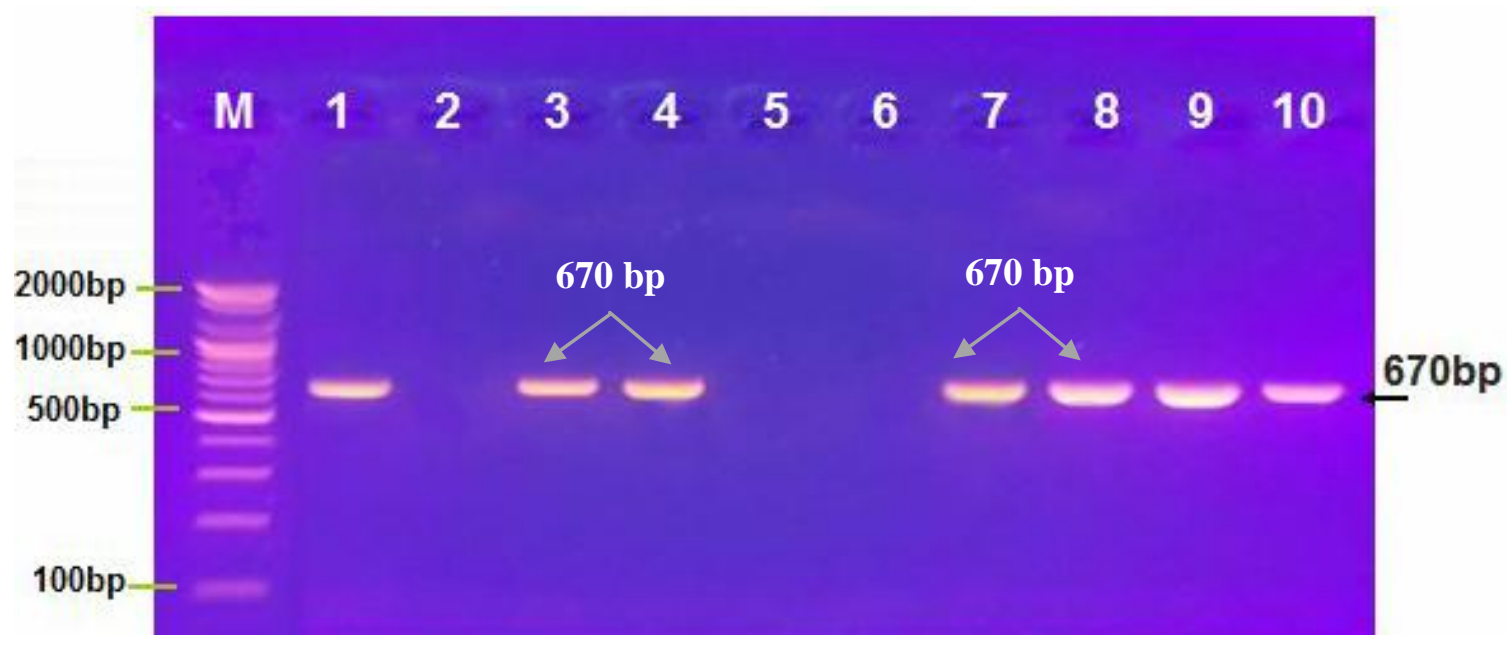

While $b l a_{\mathrm{TEM}}$ was present in $66.7 \%$ and $59.1 \%$ in burns and wounds respectively. This fact poses a serious threat to patients as these genes products mediate resistances to a wide range of antibiotics.

To avoid introduction of inappropriate antimicrobial therapy to treatment ESBLproducing bacteria; therefore, by screening those genes frequently when an ESBL is suspected in $P$. aeruginosa, can lead to the use appropriate antibiotics in treatment and help to improve the outcome of infections (Chen et al., 2015)

The prevalence of chromosomal gene "bla $a_{\mathrm{AmpC}}$ in this study was $53.3 \%$ and $50 \%$ in burns and wounds respectively, as near as proportion reported by Rafiee $R$ et al., 2014.

They reported the presence in 31 isolates $(60.8 \%)$, reflecting other difficulties in the treatment of patients infected with ESBLproducing $P$. aeruginosaby decreasing imipenem susceptibility which is a resistance mechanism in $P$. aeruginosa, by corporate AmpC $\beta$-lactamases with expanded-spectrum (Rafiee et al., 2014). The high prevalence of ESBLs genes in Diwanyia province/Iraq; is an establish fact which need further studies for detecting resistance genes of ESBL-producing strains of $P$. aeruginosa by molecular methods simultaneous with clinical characteristics of patients may help in reducing failure in the clinical treatment of multidrug resistant pathogenic bacteria.

\section{Disclosure Statement}

The authors have no conflicts of interests to declare.

\section{References}

Bahmani N, and Ramazanzadeh R. Detection of SHV type extended-spectrum Blactamase and risk factors in Pseudomonas aeruginosa clinical isolates. Pakistan J Med Sci. 2013; 29(3): 788.

Wirth FW, Picoli SU, Cantarelli V V, et al., Metallo-\$ $\beta \$$-lactamase-producing Pseudomonas aeruginosa in two hospitals from Southern Brazil. Brazilian J Infect Dis. 2009; 13(3): 170-172.

Umadevi S, Joseph NM, Kumari K, et al., Detection of extended spectrum beta lactamases, ampc beta lactamases and metallobetalactamases in clinical isolates of ceftazidime resistant Pseudomonas 
aeruginosa. Brazilian J Microbiol. 2011; 42(4): 1284-1288.

Tian G-B, Adams-Haduch JM, Bogdanovich T, Wang H-N, Doi Y. PME-1, an extendedspectrum $\$ \beta \$$-lactamase identified in Pseudomonas aeruginosa. Antimicrob Agents Chemother. 2011; 55(6): 27102713.

Peymani A, Naserpour-Farivar TN-F, Zare EZ, Azarhoosh KA. Disrtibution of blaTEM, blaSHV and blaCTX-M genes among ESBL-producing $P$. aeruginosa isolated from Qazvin and Tehran hospitals, Iran. $J$ Prev Med Hyg. 2017; 58(2): 155-160.

Bokaeian M, Zahedani SS, Bajgiran MS, Moghaddam AA. Frequency of PER, VEB, SHV, TEM and CTX-M Genes in Resistant Strains of Pseudomonas aeruginosa Producing Extended Spectrum \$ \$\$-Lactamases. Jundishapur J Microbiol. 2015; 8(1).

Jiang X, Zhang Z, Li M, Zhou D, Ruan F, Lu Y. Detection of extended-spectrum $\$ \beta \$$ lactamases in clinical isolates of Pseudomonas aeruginosa. Antimicrob Agents Chemother. 2006; 50(9): 29902995.

Rafiee R, Eftekhar F, Tabatabaei SA, Tehrani DM. Prevalence of extended-spectrum and metallo $\$ \beta \$$-lactamase production in AmpC $\quad \$ \beta \$$-lactamase producing Pseudomonas aeruginosa isolates from burns. Jundishapur J Microbiol. 2014; 7(9).

Radan M, Moniri R, Khorshidi A, et al., Emerging carbapenem-resistant Pseudomonas aeruginosa isolates carrying blaIMP among burn patients in Isfahan, Iran. Arch trauma Res. 2016; 5(3).
Polotto M, Casella T, de Lucca Oliveira MG, et al., Detection of $P$. aeruginosa harboring bla CTX-M-2, bla GES-1 and bla GES-5, bla IMP-1 and bla SPM-1 causing infections in Brazilian tertiary-care hospital. BMC Infect Dis. 2012; 12(1): 176.

Uemura S, Yokota S, Mizuno $\mathrm{H}$, et al., Acquisition of a transposon encoding extended-spectrum \$ $\beta \$$-lactamase SHV12 by Pseudomonas aeruginosa isolates during the clinical course of a burn patient. Antimicrob Agents Chemother. 2010; 54(9): 3956-3959.

Celenza G, Pellegrini C, Caccamo M, Segatore B, Amicosante G, Perilli M. Spread of bla CTX-M-type and bla PER-2 \$ $\beta \$-$ lactamase genes in clinical isolates from Bolivian hospitals. $J$ Antimicrob Chemother. 2006; 57(5): 975-978.

Zhao W-H, and $\mathrm{Hu}$ Z-Q. Epidemiology and genetics of CTX-M extended-spectrum $\$ \beta \$$-lactamases in Gram-negative bacteria. Crit Rev Microbiol. 2013; 39(1): 79-101.

Shacheraghi F, Shakibaie MR, Noveiri H. Molecular identification of ESBL Genes blaGES-blaVEB-blaCTX-M blaOXAblaOXA-4, blaOXA-10 andblaPER-in Pseudomonas aeruginosa strains isolated from burn patients by PCR, RFLP and sequencing techniques. Int J Biol life Sci. 2010; 3(6): 138-142.

Chen Z, Niu H, Chen G, Li M, Li M, Zhou Y. Prevalence of ESBLs-producing Pseudomonas aeruginosa isolates from different wards in a Chinese teaching hospital. Int J Clin Exp Med. 2015; 8(10): 19400.

\section{How to cite this article:}

Farqad A. Aljanabi, Haider A. Alnaji, Alkarar K. Duaibel. 2018. PCR for the Detection of Extended Spectrum $\quad \beta$-Lactamases Genes of Pseudomonas aeruginosa. Int.J.Curr.Microbiol.App.Sci. 7(11): 3402-3408. doi: https://doi.org/10.20546/ijcmas.2018.711.390 